\title{
Isostasy and crustal structure of the Chagos-Laccadive Ridge, Western Indian Ocean: Geodynamic implications
}

\author{
K M Sreejith ${ }^{1, *}{ }_{\mathbb{0}}, \mathrm{P}_{\text {Unnikrishnan }}^{2}$ and M Radhakrishna ${ }^{2}$ \\ ${ }^{1}$ Geosciences Division, Space Applications Centre, Ahmedabad 380 015, India. \\ ${ }^{2}$ Department of Earth Sciences, Indian Institute of Technology Bombay, Powai, Mumbai 400 076, India. \\ ${ }^{*}$ Corresponding author.e-mail: sreejith81@gmail.com
}

MS received 31 August 2018; revised 9 January 2019; accepted 13 January 2019; published online 4 June 2019

The Chagos-Laccadive Ridge (CLR), a prominent linear aseismic ridge in the Western Indian Ocean is believed to be a trace of the Réunion hotspot. In order to understand the mode of emplacement of this ridge and the nature of the underlying crust, we carried out three-dimensional (3D) flexural modelling and coherence analysis of satellite-derived gravity and bathymetry data along the ridge. The analysis revealed variations in Effective Elastic Thickness $\left(T_{\mathrm{e}}\right)$ along the CLR. While the northernmost part of CLR is associated with low $T_{\mathrm{e}}$ of $3 \mathrm{~km}$ with a subsurface to surface loading ratio $(f)$ of 1 , towards the south, the Maldive Ridge and the Chagos Bank have a fairly uniform $T_{\mathrm{e}}$ of $8-10 \mathrm{~km}$ with a very low loading ratio $f$ of $0.1-0.2$. We consider the Laccadive Ridge as a continental sliver possessing underplated magmatic rocks caused by the Réunion hotspot volcanism. The Maldive Ridge and the Chagos Bank appear to have emplaced on a lithosphere of intermediate strength possibly on the flanks of the Central Indian Ridge.

Keywords. Chagos-Laccadive Ridge; isostasy; Effective Elastic Thickness; underplating; crustal structure.

\section{Introduction}

The massive eruption of the Deccan flood basalts over western India during the Cretaceous-Tertiary $(\mathrm{K} / \mathrm{T})$ boundary ( $66 \mathrm{Ma})$ (Courtillot et al. 1988) is known to be associated with the India-Seychelles breakup. Subsequent volcanism on the Indian and African plates led to the formation of the Laccadive and Maldive ridges, the Chagos Bank and parts of the Mascarene, Mauritius and Rodrigues plateaus (Dietz and Holden 1970; Morgan 1972). Geochemical studies further suggest varying basalt compositions along the Réunion hotspot track due to the interaction of the hotspot with spreading ridge segments (Fisk et al. 1989).

Morphologically, the Chagos-Laccadive Ridge (CLR) could be divided into three main segments separated by relatively deep channels (figures 1 and 2 ). The northern segment, Laccadive Ridge, lies approximately north of $\sim 9^{\circ} \mathrm{N}$, is a plateau with several topographic highs reaching near to and above the sea level. The western boundary of the Laccadive Ridge is characterised by a steep scarp, whereas the eastern and northern boundaries have gentle slopes. The middle segment, Maldive Ridge, is an elongated topographic high, lying approximately between $7^{\circ} \mathrm{N}$ and $1^{\circ} \mathrm{S}$. The southernmost part, the Chagos Bank, is separated from the Maldive Ridge with a deep water channel of about $4500 \mathrm{~m}$ depth. The eastern boundary of the Chagos Bank has a steep scarp and coincides with the Vishnu fracture zone (Whitmarsh 1974).

Unlike the Ninetyeast and $85^{\circ} \mathrm{E}$ ridges located in the eastern Indian Ocean, some parts of the CLR 
a

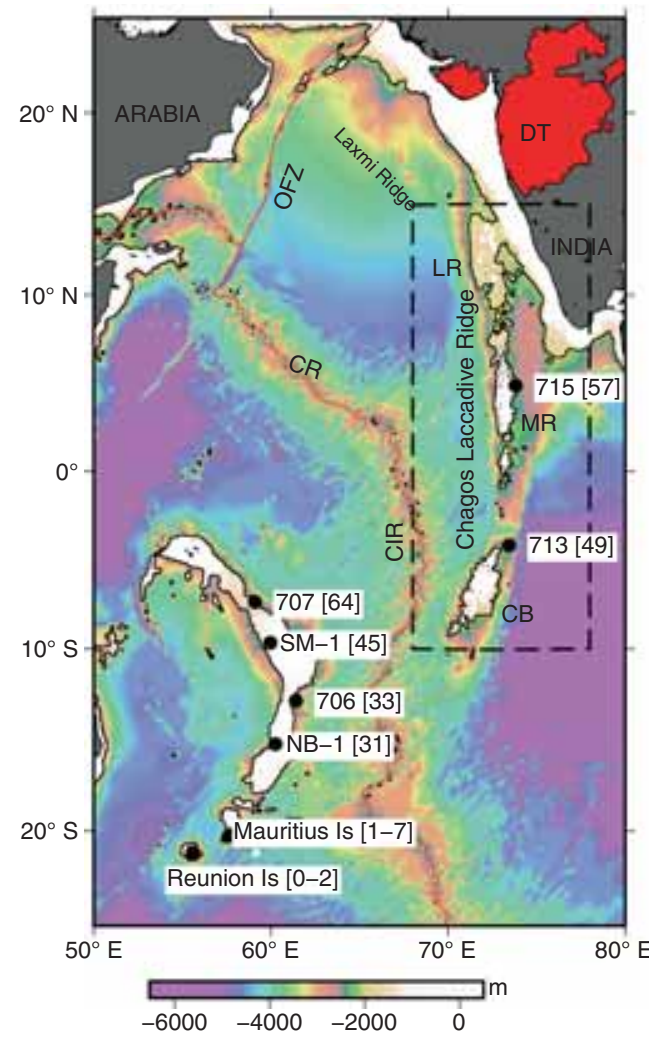

b

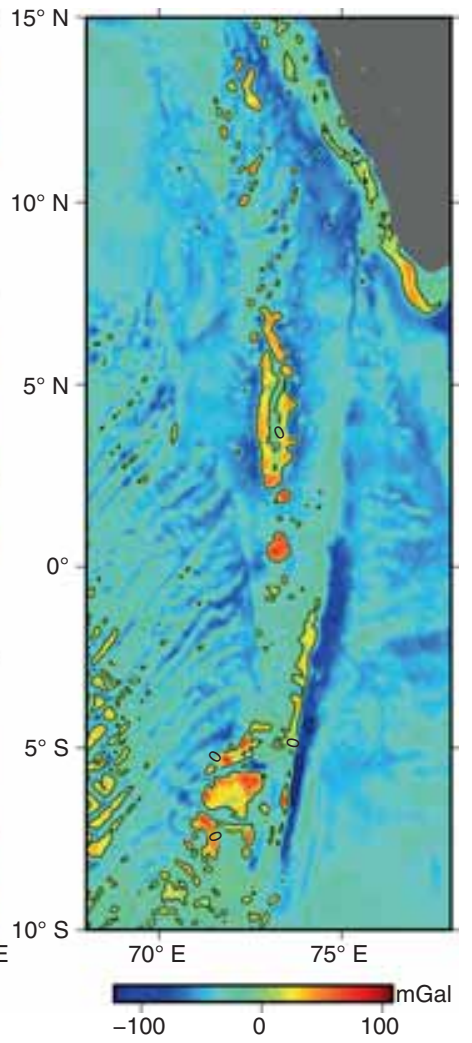

Figure 1. (a) Bathymetry map (GEBCO) of the Western Indian Ocean with a 2000-m depth contour. The study area is indicated by a thick rectangle. Positions of ODP drill sites and seismic refraction stations are shown as dark circles and red triangles, respectively. (b) Satellite-derived free-air gravity map of the study area. DT $=$ Deccan trap, OFZ $=$ Owen fracture zone, $\mathrm{CIR}=$ Central Indian Ridge, $\mathrm{CR}=$ Carlsberg Ridge, $\mathrm{LR}=$ Laccadive Ridge, $\mathrm{MR}=\mathrm{Maldive} \mathrm{Ridge}, \mathrm{CB}=$ Chagos Bank.

such as the Laccadive Islands, Maldives and Chagos Bank are believed to be the continental fragments that were severely altered by the Réunion magmatism. Narain et al. (1968) opined that the Laccadive Ridge forms a transition between the oceanic crust to the west and continental crust to the east. Based on seismic refraction data, Naini and Talwani (1983) evoked continental origin for the Laccadive Ridge. Furthermore, Murty et al. (1999) identified several rotated fault blocks from multi-channel seismic reflection data and interpreted them as continental ribbon structures associated with the Laccadive Ridge. Seismic refraction measurements just south of the Laccadive Ridge indicated volcanic rocks of thickness of about $5 \mathrm{~km}$ over a crustal layer of thickness $10 \mathrm{~km}$ and velocity $6.84 \mathrm{~km} / \mathrm{s}$ (Francis and Shor 1966). Avraham and Bunce (1977) interpreted the Maldive Ridge segment of the CLR as a micro-continent that rifted away from India probably before the Palaeocene, whereas the Chagos Bank had formed from a leaky transform fault. Torsvik et al. (2013) opined that the Chagos Bank, Maldive and Laccadive ridges along with continental fragments from the southern Mascarene plateau was part of a microcontinent 'Mauritia' that was thinned, fragmented and concealed during the Cretaceous-Cenozoic times. Recently, Kunnummal et al. (2017) observed a gradual decrease in crustal thickness from $27 \mathrm{~km}$ near the Maldive Ridge to $9 \mathrm{~km}$ near the Chagos Bank and opined that the nature of the crust could be either continental or oceanic with magmatic underplating. Shear wave velocity studies using receiver function analysis of seismic data unambiguously revealed the presence of magmatic underplating of varying degrees beneath the entire hotspot track (Gupta et al. 2010; Fontaine et al. 2015).

Transfer function analysis of bathymetry and gravity data can be used to estimate the Effective Elastic Thickness $\left(T_{\mathrm{e}}\right)$ and ratio of subsurface to surface loading $(f)$ and thereby providing constraints on the mode of isostatic compensation and crustal structure including the degree of magmatic 


\section{a}

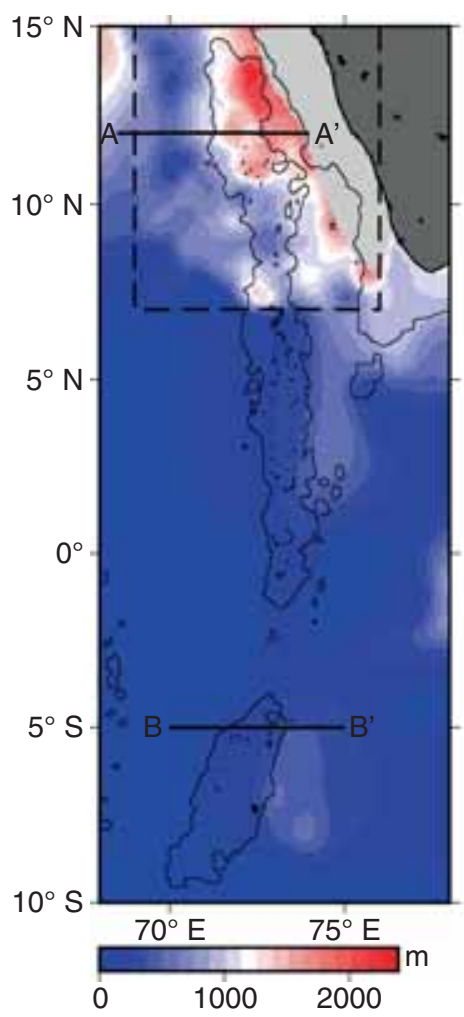

b

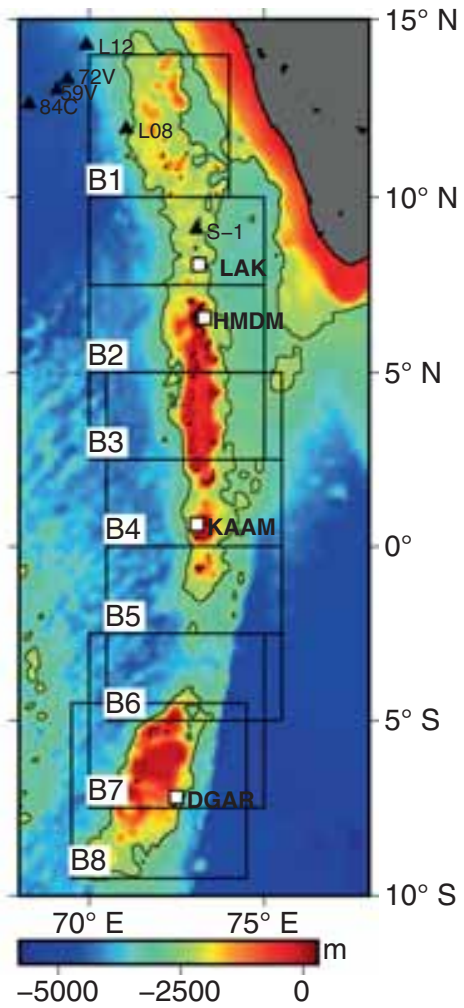

Figure 2. (a) Sediment thickness map generated from seismic and global data (Divins 2003). The high sediment thickness on the shelf is masked for better visualisation of sediment thickness variations along the CLR. The dashed box represents the extent of seismic data used for the preparation of sediment thickness data. Locations of profiles $\mathrm{AA}^{\prime}$ and $\mathrm{BB}^{\prime}$ used for forward gravity modelling are shown. (b) Basement map of CLR and the adjoining oceanic region. The positions of overlapping blocks (B1-B8) are shown. Positions of seismic refraction stations (Francis and Shor 1966; Naini and Talwani 1983) and seismograph stations (Gupta et al. 2010; Fontaine et al. 2015) are shown as black triangles and white rectangles, respectively.

underplating (e.g., McKenzie and Bowin 1976; Watts 1978; Forsyth 1985). Two-dimensional (2D) admittance analysis of the CLR (Ashalatha et al. 1991; Chaubey et al. 2008) carried out using shipborne gravity and bathymetry profiles generally suggest local compensation with very low $T_{\mathrm{e}}(<4$ $\mathrm{km})$. Ashalatha et al. (1991) computed admittance from seven ship-borne profiles from $10^{\circ} \mathrm{N}$ to $10^{\circ} \mathrm{S}$, whereas Chaubey et al. (2008) utilised 12 profiles from $8^{\circ}$ to $15^{\circ} \mathrm{N}$, covering the Laccadive Ridge region. On the other hand, Tiwari et al. (2007) carried out 3D admittance analysis of satellite gravity and bathymetry data and estimated $T_{\mathrm{e}}$ variation along the Réunion track including CLR except for the Laccadive Ridge. However, in their analysis, the variation in $T_{\mathrm{e}}$ is examined assuming a uniform loading ratio $(f=0.5)$ for the entire ridge. Similarly, Dev et al. (2007) modelled $T_{\mathrm{e}}$ for two windows covering Laccadive Ridge and a portion of the western continental margin of India (WCMI) using $f=1$. Hence, the need for a systematic investigation of $T_{\mathrm{e}}$ variation and the degree of magmatic underplating along the entire ridge is felt which may provide better constraints on the complex interaction of the Réunion hotspot with various crustal domains during the evolution of the ridge. In the present study, we investigate the variations in isostatic compensation mechanisms along the CLR using 3D flexural modelling of satellite gravity and bathymetry data. We also estimated the variations in the loading ratio along the ridge by modelling residual mantle Bouguer anomaly (RMBA) and topography coherence function to understand the variations in the degree of underplating along the CLR.

\section{Geophysical data}

Bathymetry from the general bathymetric chart of the oceans (GEBCO) and gravity from Sandwell et al. (2014) were used for the transfer function 
analysis. This recent version of satellite-derived gravity data is obtained by merging the CryoSat- 2 and Jason-1 satellite altimeter data to the existing data from ERS-1 and GEOSAT, resulting in 2-4 times improvement in accuracy than that of the previous global gravity models (e.g., Sandwell and Smith 2009).

A large number of 2D multichannel seismic profiles acquired as part of hydrocarbon exploration in the western offshore by the Oil and Natural Gas Corporation (ONGC) pertaining to the CLR $\left(8-15^{\circ} \mathrm{N}\right)$ were utilised to prepare the total sediment thickness grid of the northern part of the ridge (figure 2a). Towards the south, the sediment thickness data was obtained from the world sediment thickness grid (Divins 2003). Both these grids were merged together to obtain sediment thickness data of the entire CLR and the resulting map is presented in figure 2(a). The map reveals the presence of thicker sediments up to $2400 \mathrm{~m}$ mainly over the eastern flank of the CLR in the north (north of $8^{\circ} \mathrm{N}$ ) and the rest of the CLR is covered by only a thin layer of sediments $(100-500 \mathrm{~m})$. The bathymetry grid is corrected for the sediments by unloading them after applying isostatic corrections to obtain the basement depth map of the CLR (figure 2b).

\section{Analysis and results}

\subsection{RMBA of the CLR}

The mantle Bouguer anomalies (MBA) over the oceanic topographic features are used to understand crustal thickness variations or subsurface density heterogeneities (Kuo and Forsyth 1988). Here, the MBA data over the CLR have been generated from the free-air gravity anomaly data of the ridge by subtracting the attraction of the seafloor topography, sediments and the crust-mantle interface assuming an average 6 - $\mathrm{km}$ thick crust. However, the computed MBA values will still have the influence of thermal effects, so the gravity effects of lithosphere cooling and age-dependent subsidence have to be removed from the MBA. For this purpose, we considered the latest version of the global age grid of Müller et al. (2008) and the age-depth relation of Parsons and Sclater (1977) as reference models for the calculations. The MBA and RMBA computations were carried out using Parker (1972) algorithm. The RMBA map of the CLR is presented in figure 3.

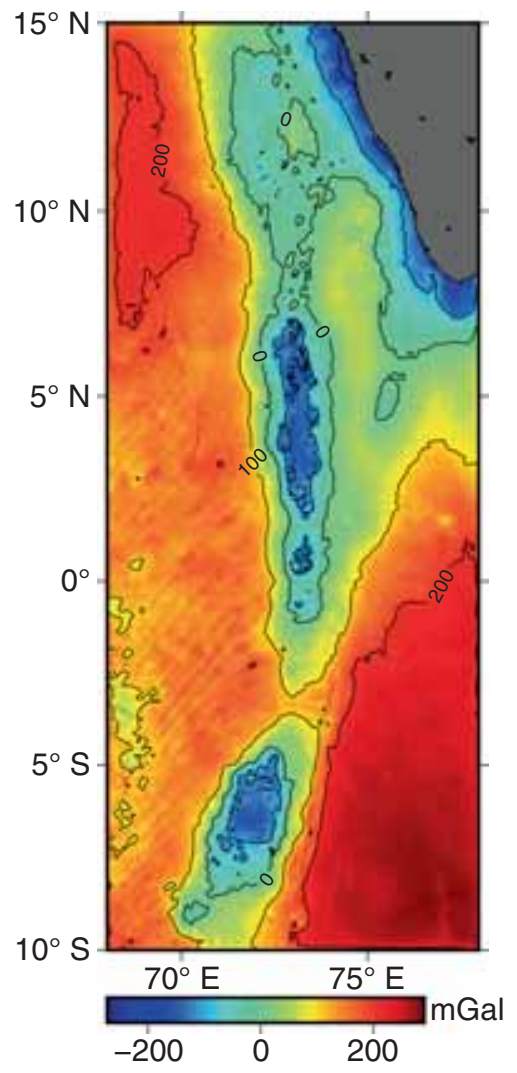

Figure 3. RMBA map of the CLR.

The RMBA values, in general, reflect the deviations in crustal thickness from a 6 - $\mathrm{km}$ normal oceanic crust and/or density distributions. The RMBA map of the CLR (figure 3) reveals that the Chagos Bank and the Maldive Ridge part of the CLR is associated with more prominent negative anomalies, reaching up to $-200 \mathrm{mGal}$ compared to the Laccadive Ridge. The prominent negative RMBA anomalies associated with the Chagos Bank and Maldive Ridge is separated by a gap near $2.5^{\circ} \mathrm{S}$ which also correlates with a gap in the topography (figure 2). The segmented pattern of the RMBA thus clearly suggests non-uniformity in crustal structure or composition along the CLR.

\subsection{Effective Elastic Thickness ( $\left.T_{\mathrm{e}}\right)$ along the $C L R$}

Gravity anomalies at the sea surface are sensitive to both topographic loads and deflections at the Moho boundary. The relationship between the topographic loads and underlying Moho deflections as well as the gravity response to each can be described in the Fourier domain, considering the elastic plate approximations (Watts 2001) to be 
Table 1. Model parameters used for the flexural computations.

\begin{tabular}{ll}
\hline Parameter & \multicolumn{1}{c}{ Value } \\
\hline Density of sea-water $\left(\rho_{\mathrm{w}}\right)$ & $1.03 \mathrm{~g} / \mathrm{cm}^{3}$ \\
Density of oceanic crust $\left(\rho_{\mathrm{c}}\right)$ & $2.80 \mathrm{~g} / \mathrm{cm}^{3}$ \\
Density of mantle $\left(\rho_{\mathrm{m}}\right)$ & $3.30 \mathrm{~g} / \mathrm{cm}^{3}$ \\
Average crustal thickness $(t)$ & $7 \mathrm{~km}$ \\
Young's modulus $(E)$ & $100 \mathrm{GPa}$ \\
Poisson's ratio $(\sigma)$ & 0.25 \\
Universal gravitational & $6.67 \times 10^{-11} \mathrm{~N} \mathrm{~m}^{2} / \mathrm{kg}^{2}$ \\
$\quad$ constant $(G)$ & $9.8 \mathrm{~m} / \mathrm{s}^{2}$ \\
Acceleration due to & \\
gravity $(g)$ &
\end{tabular}

$\Delta g(k)=2 \pi G\left(\rho_{\mathrm{l}}-\rho_{\mathrm{w}}\right) \mathrm{e}^{-k d}\left(1-\varphi_{\mathrm{e}}(k) \mathrm{e}^{-k t}\right) H(k)$,

where $\Delta g(k)$ and $H(k)$ represent the Fourier transforms of gravity anomaly and topography, respectively, and $\varphi_{\mathrm{e}}(k)=\left[1+\left(D k^{4} / g\left(\rho_{\mathrm{m}}-\rho_{\mathrm{c}}\right)\right)\right]^{-1}$. $D$ is the flexural rigidity and is related to $T_{\mathrm{e}}$ as

$$
D=\frac{E T e^{3}}{12\left(1-\nu^{2}\right)}
$$

The parameters in the above expressions are described in table 1.

In the flexural modelling, the gravity effect of the bathymetry and its compensation is computed for a range of $T_{\mathrm{e}}$ values, and the computed gravity anomalies are compared with the observed anomalies. Traditionally, the best-fitting $T_{\mathrm{e}}$ is considered based on the minimum RMS error criteria. Analyses of several profiles along the CLR reveal that the best-fit $T_{\mathrm{e}}$ is not tightly constrained by a simple RMS error method as it does not contain information about the anomaly shape. Hence, we use an objective function as formulated by Smith et al. (1989), which combines the RMS error and correlation coefficient between the observed and modelled gravity for determining the best-fit $T_{\mathrm{e}}$ values. The objective function is defined as

$$
\text { obfn }=0.5\left[\frac{\mathrm{RMS}}{\mathrm{RMS}_{\max }}+R^{2}\right],
$$

where $\mathrm{RMS}_{\max }$ is the maximum RMS error of all models and $R^{2}$ represents the correlation coefficient between the topography and the modelled gravity anomaly. The upper and lower bounds of $T_{\mathrm{e}}$ are determined using the intersection of the line defined by obfn $\min *(1+x)$, on the obfn curve, where $x$ is the tolerance parameter defined as $5 \%$ of the obfn $_{\text {min }}$. The model parameters used for the computation of the flexural model are listed in table 1.

In this study, we carried out 3D flexural modelling for the eight overlapping grids to obtain variations in $T_{\mathrm{e}}$ along the entire length of the CLR. Previously, Sreejith and Krishna (2013) carried out 2D flexural modelling along the Ninetyeast Ridge to understand finer variations in $T_{\mathrm{e}}$ along the ridge. Theoretically, a 2D modelling of a 3D geological feature is based on the assumption that the feature is infinitely long and the profile is perpendicular to the feature. However, by the thumb rule, the length of the feature should be $>250 \mathrm{~km}$ for the safe assumption of two dimensionality (Ribe 1982). Considering the rugged topography of CLR, we prefer 3D flexural modelling along eight overlapping blocks (B1-B8) for reliable $T_{e}$ estimation (figure $2 \mathrm{~b}$ ). The objective function misfit curves and best-fit $T_{\mathrm{e}}$ estimates with upper and lower limits for each block are presented in figure 4(a) and table 2 , respectively. The above analysis gave rise to $T_{\mathrm{e}}$ values of about $8-10 \mathrm{~km}$ for the blocks B3-B8 covering the Chagos Bank and Maldive Ridge part of the CLR, and a low $T_{\mathrm{e}}$ value of $3 \mathrm{~km}$ for the block B1 over the Laccadive Ridge. We run the model over a range of spatial windows along the ridge and found that the transition from low $T_{\mathrm{e}}$ to intermediate $T_{\mathrm{e}}$ values occur around $9^{\circ} \mathrm{N}$, the southern limit of the Laccadive Ridge. The flexural computations were made assuming a simple one-layer crust of average density $2.85 \mathrm{~g} / \mathrm{cm}^{3}$ over a mantle layer of density $3.3 \mathrm{~g} / \mathrm{cm}^{3}$. The gravity response from the derived crust-mantle interface (flexure Moho) and the seafloor-water has been compared with the observed gravity anomalies along selected profiles from each of the blocks and are presented in figure $4(\mathrm{~b})$.

\subsection{RMBA-residual topography coherence analysis}

The traditional way of determining the $T_{\mathrm{e}}$ is usually by comparing the observed and theoretical admittance function (Watts 1978, 2001). In this method, the theoretical admittance is calculated by loading elastic lithosphere from above (surface) and below (subsurface or underplating). The best-fit model is obtained by changing three unknown parameters: $T_{\mathrm{e}}$, depth to the subsurface load $\left(z_{-} d\right)$ and the subsurface to the surface loading ratio $(f)$. However, in this approach, a strong plate with a subsurface load and a weak plate with surface loading may provide similar admittance results. 
Thus, different models having different $T_{\mathrm{e}}$ may match with the observed admittance, thereby making the interpretations non-unique (Forsyth 1985). To overcome this uncertainty, an improved method based on the coherence analysis between RMBA and topography is considered here for a robust determination of $T_{\mathrm{e}}$ and subsurface loading (after Forsyth 1985; Luis and Neves 2006). Coherence is defined as

$$
\gamma^{2}(k)=\frac{C(k) C^{*}(k)}{E_{\mathrm{g}}(k) E_{\mathrm{t}}(k)},
$$

where $C(k)$ is the cross-spectrum of bathymetry and gravity, $E_{\mathrm{g}}(k)$ and $E_{\mathrm{t}}(k)$ are the power spectra of gravity and topography, respectively. The theoretical coherence between RMBA and topography can be computed from

$$
\gamma^{2}(k)=\frac{\left(1+(f / \xi(k))^{2} \varphi(k)\right)^{2}}{\left(1+(f / \xi(k))^{2}\right)\left(1+f^{2} \varphi(k)^{2}\right)},
$$

where $\xi(k)=\left[1+\left(D k^{4} / g\left(\rho_{\mathrm{m}}-\rho_{\mathrm{c}}\right)\right)\right]^{-1}$ and $\varphi(k)=$ $\left[1+\left(D k^{4} / g\left(\rho_{\mathrm{c}}-\rho_{\mathrm{w}}\right)\right)\right]^{-1}$.

RMBA-residual topography coherence is computed for eight overlapping blocks on CLR, as used for the flexural modelling. Theoretical coherence was computed for a range of loading ratios and using $T_{\mathrm{e}}$ values as obtained from the $3 \mathrm{D}$ flexural modelling for each of these blocks. The coherence vs. wavelength plot (figure 5) shows a typical drop in coherence from 1 to 0.1 for the waveband 50 $200 \mathrm{~km}$, indicating transition from compensated to uncompensated topography and considered as a diagnostic waveband for lithospheric flexure (Watts 2001). The observed and theoretical coherence was compared in this transitional waveband to find out the best-fit loading ratio. On the whole, the coherence analysis suggests the presence of subsurface loading beneath the entire CLR with a variable degree of loading, ranging from 0.1 to 1 . The Laccadive Ridge (B1) is associated with a high loading ratio of 1 , whereas, blocks $3-8$, representing the Chagos Bank and Maldive Ridge, show low loading ratios of $0.1-0.2$, block 2 , partly covering the Laccadive Ridge shows an intermediate value of $0.3-0.4$.

\subsection{Forward gravity model}

We incorporated the above results on $T_{\mathrm{e}}$ and $f$ variation over the ridge and carried out $2 \mathrm{D}$ forward gravity modelling to derive the crustal structure along two profiles $\mathrm{AA}^{\prime}$ and $\mathrm{BB}^{\prime}$, which traverse across Laccadive Ridge and Chagos Bank, respectively. Seismic refraction results from oceanic and adjoining continental regions were utilised to identify the density and thickness of the crustal layers (Francis and Shor 1966; Kaila et al. 1979; Naini and Talwani 1983). Seismic refraction studies near the western flank of Laccadive Ridge suggests velocities of $5.6,6.2$ and $6.9 \mathrm{~km} / \mathrm{s}$ corresponding to volcanic rocks $\left(2.6 \mathrm{~g} / \mathrm{cm}^{3}\right)$, upper continental crust $\left(2.75 \mathrm{~g} / \mathrm{cm}^{3}\right)$ and lower continental crust $\left(2.85 \mathrm{~g} / \mathrm{cm}^{3}\right)$, respectively. Seismic refraction studies in the adjacent oceanic basins of CLR suggest velocities of $5.1-6.3 \mathrm{~km} / \mathrm{s}$ (Layer 2) and $6.4-7.0 \mathrm{~km} / \mathrm{s}$ (Layer 3). For the crustal model,
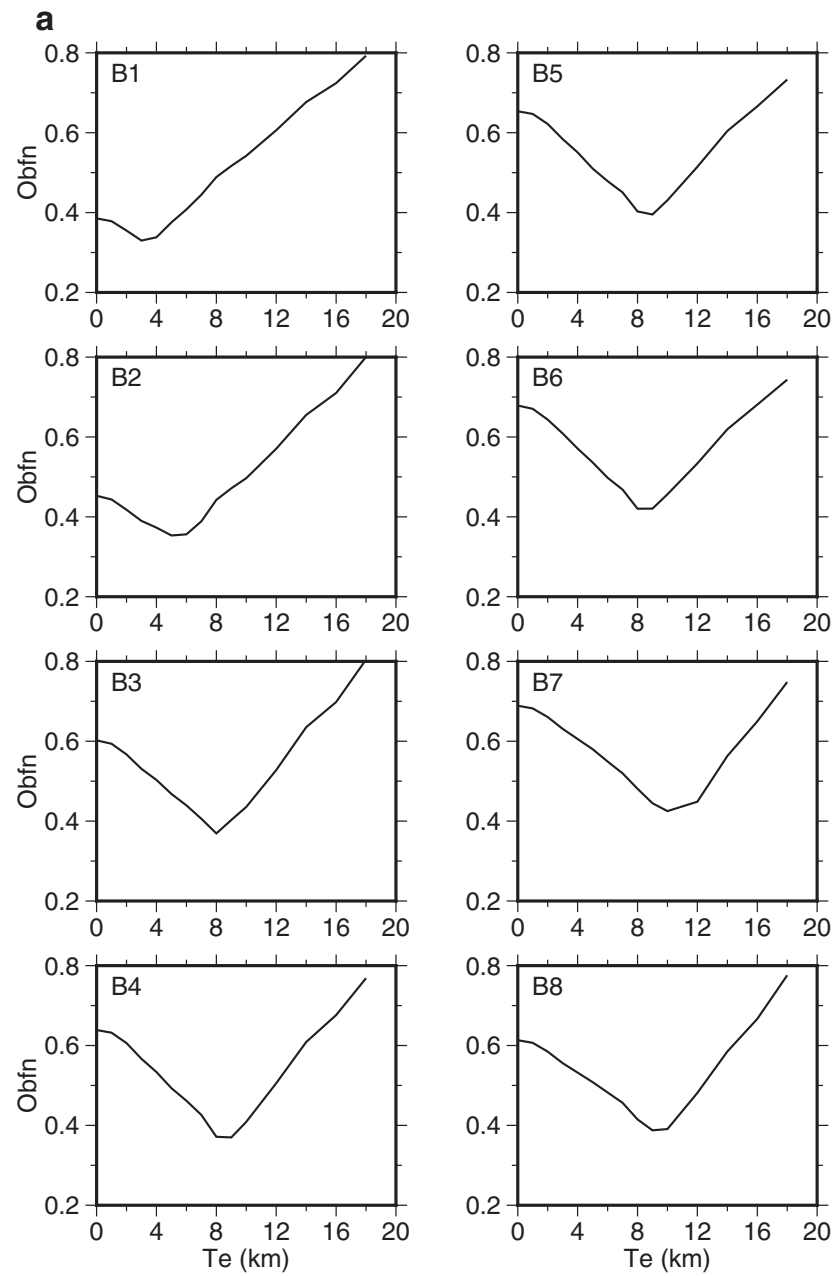

Figure 4. (a) Objective function misfit for 3D flexural modelling along blocks B1-B8. The best-fit $T_{\mathrm{e}}$ with error bounds are listed in table 2. (b) Gravity model depicting the gravity response of bathymetry and flexure Moho along the E-W profiles corresponding to the best-fit $T_{\mathrm{e}}$ from blocks B1-B8. The RMBA extracted along the gravity profile is also shown as a grey line. Thick vertical lines in B1 represent the extent of the Laccadive Ridge inferred from seismic reflection data. 

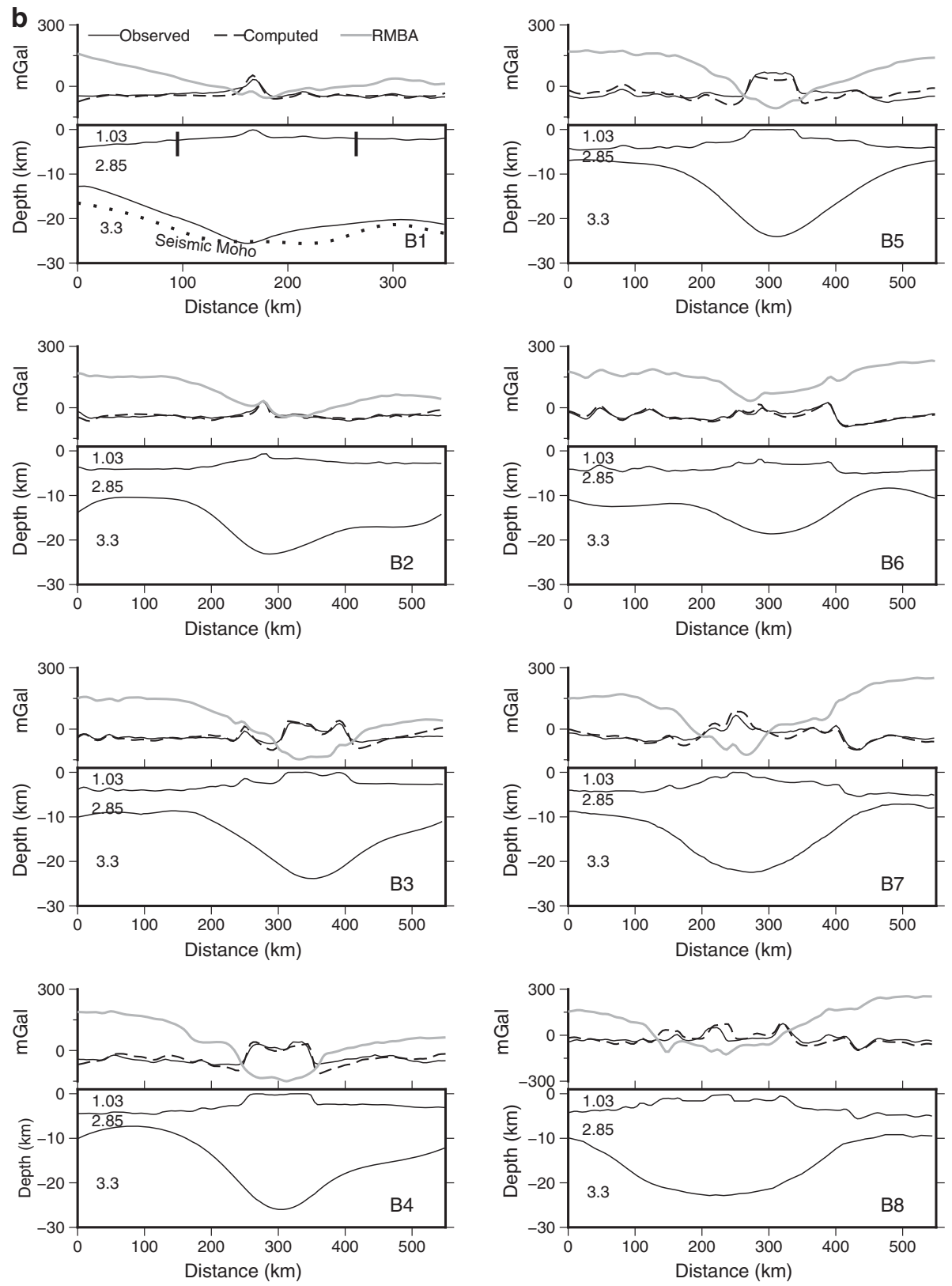

Figure 4. (Continued.)

Table 2. Best fit $T_{\mathrm{e}}$ with lower and upper limits and subsurface to surface loading ratio $(f)$ along CLR obtained from gravity-topography flexural modelling and RMBA-topography coherence analysis.

\begin{tabular}{lcccccc}
\hline \multirow{2}{*}{$\begin{array}{c}\text { Block } \\
\text { number }\end{array}$} & $\begin{array}{c}\text { Centre } \\
\text { latitude } \\
(\mathrm{deg})\end{array}$ & $\begin{array}{c}\text { Lower } \\
\text { limit }\end{array}$ & $\begin{array}{c}\text { Best } \\
\text { fit }\end{array}$ & $\begin{array}{c}\text { Upper } \\
\text { limit }\end{array}$ & $f$ & $\begin{array}{c}T_{\mathrm{e}} \\
\text { (Tiwari } \text { et al. 2007), }\end{array}=0.5, z=18-20 \mathrm{~km}$ \\
\hline B1 & 12 & 2.0 & 3 & 3.4 & 1 & 2 \\
B2 & 7.5 & 4 & 5 & 6.4 & $0.3-0.4$ & 4 \\
B3 & 5 & 7.4 & 8 & 8.5 & 0.1 & 5 \\
B4 & 2.5 & 7.7 & 8 & 9.5 & $0.1-0.2$ & 4 \\
B5 & 0 & 7.7 & 9 & 9.5 & 0.2 & 6 \\
B6 & -2.5 & 7.6 & 9 & 9.6 & 0.2 & 6 \\
B7 & -5 & 9 & 10 & 11.8 & $0.1-0.2$ & 6 \\
B8 & -7 & 8.3 & 9 & 10.4 & 0.2 & 6 \\
\hline
\end{tabular}



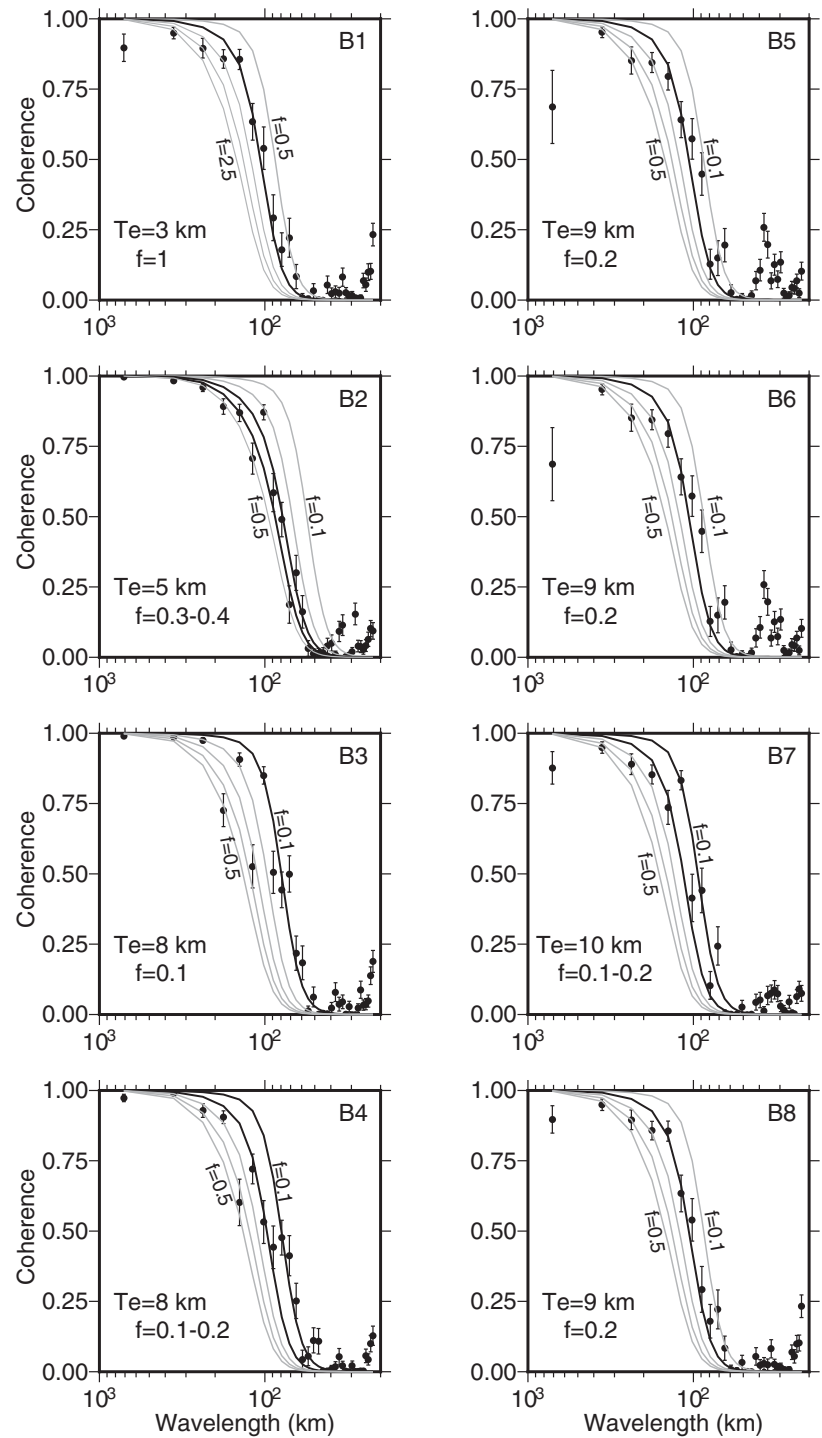

Figure 5. Observed coherence between RMBA and the residual topography (dots) of the CLR for blocks 1-8 along with the theoretical coherence curves (solid lines) for various loading ratios. Black lines represent theoretical curves corresponding to best-fit $f$ values. Theoretical coherence curves are computed using the best-fit $T_{\mathrm{e}}$ obtained (table 2 ) for the respective blocks.

we assigned average densities of 2.7 and $2.9 \mathrm{~g} / \mathrm{cm}^{3}$ for oceanic crustal Layers 2 and 3, respectively. We also included underplated rocks of density $3.0 \mathrm{~g} / \mathrm{cm}^{3}$ below the lower crust. Considering the results of the RMBA-topography coherence analysis, the thickness of the underplated rocks are considered as $100 \%$ and $15 \%$ of that of volcanic rocks for the Laccadive Ridge and Chagos Bank, respectively. The Moho surface (as suggested by the best-fit $T_{\mathrm{e}}$ ) and crustal layers below the ridge have been marginally adjusted to provide a reasonable fit between the observed and computed gravity anomalies along these two profiles.

\section{Discussion}

\subsection{Effective Elastic Thickness and loading ratio variations along $C L R$}

Flexural modelling as well as the coherence analysis of the CLR clearly revealed that the Laccadive Ridge is characterised by a low $T_{\mathrm{e}}$ value of $3 \mathrm{~km}$ and associated with a subsurface loading (underplating) equal to that of the surface loading. The southern boundary of the Laccadive Ridge is well marked with a prominent break in the basement structure and RMBA (figures 1-3). Nair et al. (2013) have noted different NE-SW anomaly pattern in filtered free-air gravity maps, which clearly separate the Laccadive Ridge from the rest of the CLR north of $8-9^{\circ} \mathrm{N}$. While the $T_{\mathrm{e}}$ value of $3 \mathrm{~km}$ estimated here for the Laccadive Ridge agrees well with that of Chaubey et al. (2008), it slightly differs from the estimate of $\left(T_{\mathrm{e}}=5 \mathrm{~km}\right)$ by Dev et al. (2007). The discrepancy could be due to a relatively larger window size, which partly covers the western continental shelf used by them in their analysis. Towards the south, the Maldive Ridge and the Chagos Bank are associated with uniform $T_{\mathrm{e}}$ values of $8-10 \mathrm{~km}$ with a very low subsurface loading of $f=0.1$ ( $10 \%$ of surface loading). Tiwari et al. (2007) estimated rather low $T_{\mathrm{e}}$ of $4-6 \mathrm{~km}$ for the Maldive Ridge and the Chagos Bank using 3D admittance analysis. The difference could probably be that Tiwari et al. (2007) estimated $T_{\mathrm{e}}$ by varying depth to the load with the assumption of constant subsurface to surface loading $(f=0.5)$ for the entire ridge. However, it should be noted that non-uniform melt production and/or lithospherehotspot interactions can cause spatial variations in $f$ and the crustal thickness as reported for the Ninetyeast Ridge (Sreejith and Krishna 2013, 2015). The RMBA-residual topography coherence method employed in the present study has provided an unbiased estimation of $f$ and its spatial variations along the CLR.

\subsection{Crustal structure}

Gravity response of crustal models corresponding to the best-fit $T_{\mathrm{e}}$ provides a reasonable match with the observed gravity anomalies (figure $4 \mathrm{~b}$ ). Below the Laccadive Ridge, the flexure Moho is an excellent match with the seismically derived Moho (figure 4b). The depth and overall shape of the Moho topography also matches well with that derived using the forward gravity model along 

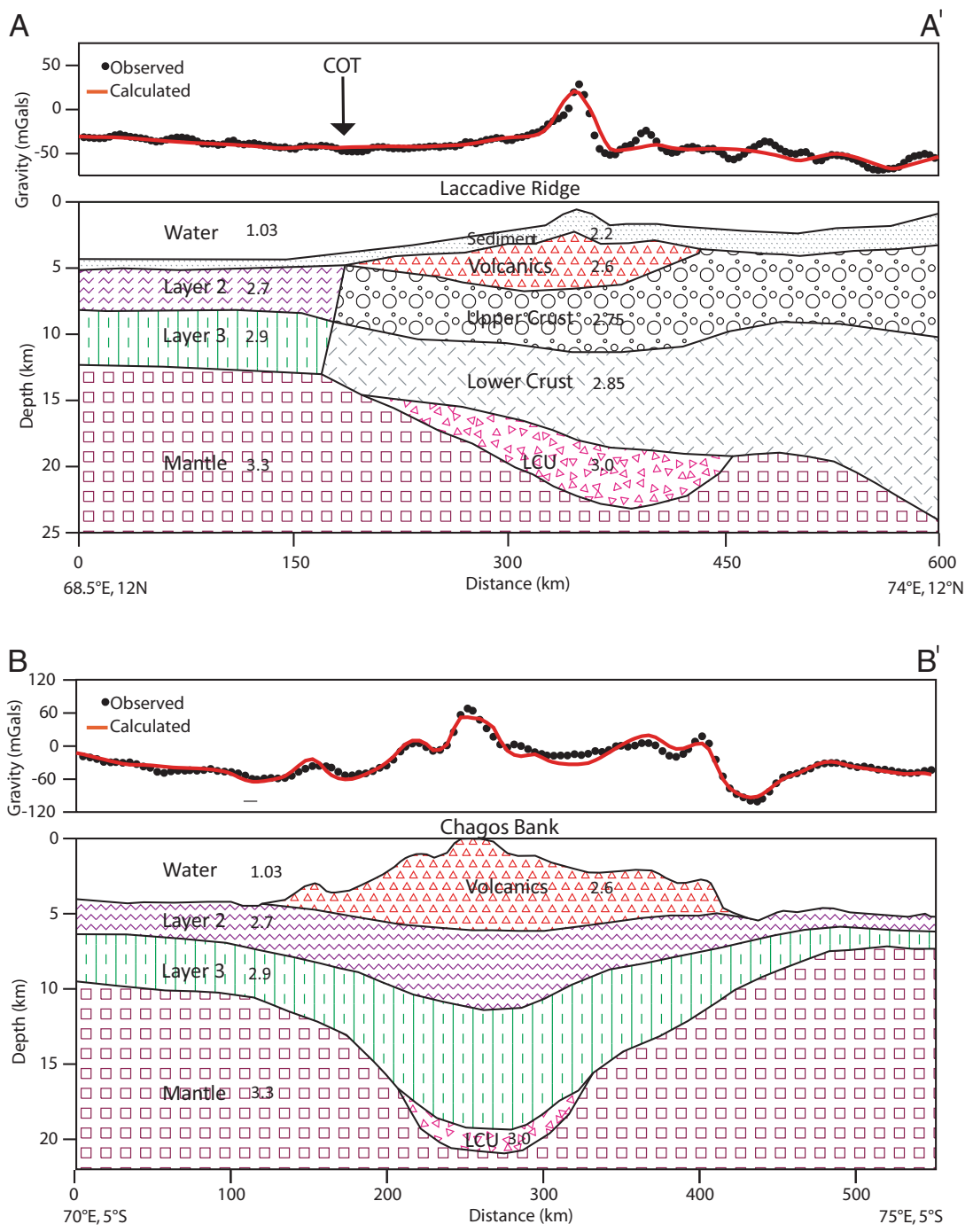

Figure 6. Crustal models derived using 2D forward gravity modelling along profiles $\mathrm{AA}^{\prime}$ and $\mathrm{BB}^{\prime}$. Profile locations are provided in figure 2(a). Densities in $\mathrm{g} / \mathrm{cc}$ are indicated on the respective layers. OCT in profile AB stands for ocean continent transition.

profile $\mathrm{AA}^{\prime}$ (figure 6). The forward gravity model suggests that the western boundary of the Laccadive Ridge marks the transition from the oceanic crust to the continental crust. The model also suggests a lower crustal underplating of thickness equal to that of the volcanic load. The present crustal model agrees well with that of Radha Krishna et al. (2002), Ajay et al. (2010) and Arora et al. (2012). However, it differs considerably from that of Chaubey et al. (2002) and Nair et al. (2013), as these models did not consist of high-density underplated rocks beneath the lower crust.

Towards the south, the flexure Moho below the Maldive Ridge (B3-B6) is comparable to the Moho topography derived using gravity inversion (Henstock and Thompson 2004; Kunnummal et al. 2017) and mean depth to Moho (23-28 km) estimated from receiver function studies (Fontaine et al. 2015). Below Chagos Bank, the depth and wavelength of flexure Moho matches well with that derived from the 2D forward gravity model along profile BB' (figure 6). In addition, the forward gravity model also suggests a thin layer of underplated rocks $(\sim 1 \mathrm{~km})$ below the lower crust. However, Fontaine et al. (2015) suggested a slightly shallow depth of $17 \mathrm{~km}$ for the Moho boundary using receiver function studies.

\subsection{Geodynamic implications}

We examine different possibilities of interpreting the low $T_{\mathrm{e}}$ value obtained for the Laccadive Ridge. It is known very well that $T_{\mathrm{e}}$ values largely depend on the strength of the lithosphere at the time of emplacement (Watts 2001). A low $T_{\mathrm{e}}$ generally suggests volcanic emplacement near the spreading 
centre. However, the breakup history of the WCMI and the age progression along the Réunion hotspot track clearly suggest that the Réunion hotspot could not have had an on-ridge eruption at least until $47 \mathrm{Ma}$ (Duncan 1990). The second possibility is the off-ridge emplacement of the Laccadive Ridge followed by thermal rejuvenation which could have changed the flexural rigidity of the lithosphere causing a resetting of the $T_{\mathrm{e}}$ to a lower value due to the prolonged interaction of the hotspot with the oceanic crust. The lower $T_{\mathrm{e}}$ associated with the Cape Verde rise in the Atlantic Ocean (Young and Hill 1986; McNutt 1988) and Magellan seamounts in the Pacific Ocean (Smith et al. 1989) is believed to have been caused by the prolonged interaction of a causative hotspot with a slow moving plate. However, plate tectonic models suggest that the velocity of the Indian plate was exceptionally high from the arrival of Réunion plume (66 Ma) until the India-Eurasia collision (52 Ma). Hence, the low $T_{\mathrm{e}}$ for the Laccadive Ridge could not be explained by either an on-ridge or off-ridge emplacement on the oceanic lithosphere.

The evolution of WCMI involves two major rift-drift events and associated hotspot volcanisms: (i) the late-Cretaceous rifting of Madagascar, probably when the Marion hotspot was in close proximity, and (ii) the Réunion plume arrival followed by the breakup of Seychelles from India during the early Tertiary. Though the Marion hotspot caused widespread volcanism along the eastern Madagascar margin, along WCMI, the intensity of magmatism is low and has been restricted to the southern part (Radhakrishna et al. 1994; Storey et al. 1995; Torsvik et al. 2000; Kumar et al. 2001). The relatively moderate $T_{\mathrm{e}}(10-15 \mathrm{~km})$ reported for the southern WCMI using process-oriented gravity modelling (Chand and Subrahmanyam 2003; Dev et al. 2007) also suggests that no significant reduction in lithospheric strength has been observed despite the traverse of the Marion hotspot during the rifting. This is also evident from the high $T_{\mathrm{e}}(15 \mathrm{~km})$ reported for the continental portion of the Comorin Ridge compared to the low $T_{\mathrm{e}}$ of $2-3 \mathrm{~km}$ of its oceanic part (Sreejith et al. 2008). In contrast to the Marion, the Réunion hotspot activity was more intense at the northern part of WCMI and must have caused significant weakening of the lithosphere as indicated by low $T_{\mathrm{e}}=5 \mathrm{~km}$ (Dev et al. 2007). We conclude that the lithospheric stretching during the rifting stage followed by Réunion hotspot volcanism must have caused both weakening of lithospheric strength and sub-crustal magmatic underplating beneath the Laccadive Ridge. It is noteworthy that the seismic velocity structure of the Laccadive Ridge closely matches with that of the Laxmi Ridge, which is considered as a continental sliver (Naini and Talwani 1983; Bhattacharya et al. 1994; Talwani and Reif 1998; Todal and Eldholm 1998; Radha Krishna et al. 2002; Krishna et al. 2006; Minshull et al. 2008; Mishra et al. 2018). The continental nature of the Laccadive Ridge is further supported by the identification of seaward dipping reflectors on seismic reflection profiles from the western flank of the Laccadive Ridge (Ajay et al. 2010).

Large subsurface loading for the Laccadive Ridge must have caused by the accumulation of magmatic rocks by the Réunion hotspot volcanism during early Tertiary at the base of the relatively thicker continental crust. Receiver function studies suggest thinning of an underplated layer southwards from 10 to $1 \mathrm{~km}$ beneath the Seychelles archipelago (Hammond et al. 2013). The low loading ratio towards the south could have been caused by lesser magma input during the waning stage of the Réunion plume. Secondly, the southern portion of the CLR was emplaced on a fast-moving Indian plate which might have hampered prolonged interaction between the hotspot and the lithosphere required for significant subsurface loading process.

Moderate $T_{\mathrm{e}}$ of 8-9 $\mathrm{km}$ inferred for the Maldive Ridge could be explained by emplacement near the flanks of CIR as suggested by the plate reconstruction models and age data from the ODP drill site 715 (Malod et al. 1997; Royer et al. 2002). However, during early Oligocene (33 Ma), the Réunion hotspot was probably located under a segment of the Central Indian Ridge and supplying melt to the southern Chagos Bank as well as to the Nazareth bank. A ridge-hotspot interaction typically causes very low $T_{\mathrm{e}}$ values as observed for the Ninetyeast Ridge. However, moderate $T_{\mathrm{e}}$ values estimated for both the Chagos Bank $\left(T_{\mathrm{e}}=9-10\right)$ and Nazareth bank $\left(T_{\mathrm{e}}=13 \mathrm{~km}\right)$ (Tiwari et al. 2007) could be due to the rapid emplacement of the ridge due to volcanism on a fast-moving Indian plate (about $125 \mathrm{~mm} / \mathrm{yr}$ during 60-50 Ma). Recently, Torsvik et al. (2013) proposed that the Chagos Bank is a continental fragment, which separated from the conjugate Mascarene plateau as a result of the onset of the Réunion plume. This model suggests that the Réunion plume remained directly beneath the Indian plate only for $\sim 10 \mathrm{Myr}$ (65-55 Ma) and later volcanism was caused when it was under the African plate. Although this model 
can explain the moderate $T_{\mathrm{e}}$ value for the Maldive Ridge and Chagos Bank, an unequivocal inference on the nature of the crust needs further studies. Indeed the seismic refraction results (Francis and Shor 1966) from the southern Maldive Ridge and the northern portion of the Chagos Bank suggest lower crustal velocities typical of volcanic islands $(6.13-6.79 \mathrm{~km} / \mathrm{s})$.

\section{Conclusions}

Transfer function analyses of bathymetry and gravity data of the CLR along eight overlapping blocks have provided new constraints on the elastic thickness and crustal underplating variations along the ridge.

(1) The northern most part of the CLR chain (Laccadive Ridge) is associated with low $T_{\mathrm{e}}$ of $3 \mathrm{~km}$ with a subsurface to surface loading ratio of 1 . However, towards the south, the Maldive Ridge and the Chagos Bank Ridge have fairly uniform $T_{\mathrm{e}}$ of $8-10 \mathrm{~km}$ with a very low loading ratio of $0.1-0.2$.

(2) The Laccadive Ridge was emplaced on a stretched continental crust in the presence of sub-crustal underplated rocks of thickness similar to the surface load.

(3) The Maldive Ridge and the Chagos Bank might have been emplaced by the Réunion hotspot on the flanks of the Central Indian Ridge. The low subsurface loading inferred for the southern part of the chain could be related with the rapid emplacement on the fast-moving Indian plate.

\section{Acknowledgements}

The present study was undertaken as part of the ISRO-sponsored project under the MOP-III scheme of SAC and IITB. The authors are thankful to SAC-ISRO for financial support. A S Rajawat, Raj Kumar and D K Das from SAC have supported the studies. The figures were prepared using GMT software (http://gmt.soest.hawaii.edu/).

\section{References}

Ajay K K, Chaubey A K, Krishna K S, Gopala Rao D and Sar D 2010 Seaward dipping reflectors along the SW continental margin of India: Evidence for volcanic passive margin; J. Earth Syst. Sci. 119 803-813.

Arora K, Tiwari V M, Singh B, Mishra D C and Grevemeyer I 2012 Three dimensional lithospheric structure of the western continental margin of India constrained from gravity modelling: Implication for tectonic evolution; Geophys. J. Int. 190 131-150.

Ashalatha B, Subrahmanyam C and Singh R N 1991 Origin and compensation of Chagos-Laccadive Ridge, Indian ocean from admittance analysis of gravity and bathymetry data; Earth Planet. Sci. Lett. 105 47-54.

Avraham Z B and Bunce E T 1977 Geological study of the Chagos-Laccadive Ridge, Indian ocean; J. Geophys. Res. 82 1295-1305.

Bhattacharya G C, Chaubey A K, Murty G P S, Srinivas K, Sarma K V L N S, Subrahmanyam V and Krishna K S 1994 Evidence for seafloor spreading in the Laxmi Basin, northeastern Arabian Sea; Earth Planet. Sci. Lett. 125 211-220.

Chand S and Subrahmanyam C 2003 Rifting between India and Madagascar - Mechanism and isostasy; Earth Planet. Sci. Lett. 210 17-332.

Chaubey A K, Gopala Rao D, Srinivas K, Ramprasad T, Ramana M V and Subrahmanyam V 2002 Analysis of multichannel seismic reflection, gravity and magnetic data along a regional profile across the central-western continental margin of India; Mar. Geol. 182 303-323.

Chaubey A K, Srinivas K, Ashalatha B and Rao D G 2008 Isostatic response of the Laccadive Ridge from admittance analysis of gravity and bathymetry data; J. Geodyn. 46 $10-20$.

Courtillot V, Féraud G, Maluski H, Vandamme D, Moreau M G and Besse J 1988 Deccan flood basalts and the Cretaceous/Tertiary boundary; Nature 333 843846.

Dev S V, Radhakishna M and Subrahmanyam C 2007 Estimates of Effective Elastic Thickness along the Southwest Continental Margin of India using coherence analysis of gravity and bathymetry data - Geodynamic implications; J. Geol. Soc. India 70 475-487.

Dietz R S and Holden J C 1970 Reconstruction of Pangaea: Breakup and dispersion of continents, Permian to Present; J. Geophys. Res. 75 4939-4956.

Divins D L 2003 Total sediment thickness of the world's oceans \& marginal seas; NOAA National Geophysical Data Center, Boulder, Colorado, USA.

Duncan R A 1990 The volcanic record of the Reunion hotspot; In: Proceedings of the ocean drilling program, scientific results (eds) Duncan R A, Backman J and Peterson L C et al. 115 College Station, TX (Ocean Drilling Program), pp. 3-10.

Fisk M R, Duncan R A, Baxter A N, Greenhough J D, Hargraves R B and Tastsumi Y et al. 1989 Reunion hotspot magma chemistry over the past $65 \mathrm{Ma}$ : Results from Leg 115 of the ocean drilling program; Geology 17934 937.

Fontaine F R, Barruol G, Tkalčić H, Wölbern I, Rümpker G, Bodin T and Haugmard M 2015 Crustal and uppermost mantle structure variation beneath La Réunion hotspot track; Geophys. J. Int. 203 107-126.

Forsyth D W 1985 Subsurface loading and estimates of the flexural rigidity of continental lithosphere; J. Geophys. Res. 90 12,623-12,632.

Francis T J G and Shor G G 1966 Seismic refraction measurements in the northwest Indian ocean; J. Geophys. Res. 71 427-449. 
GEBCO 1-Minute global bathymetric grid; https://www. gebconet/data_and_products/gridded_bathymetry_data/ gebco_one_minute_grid.

Gupta S, Mishra S and Rai S S 2010 Magmatic underplating of crust beneath the Laccadive Island, NW Indian ocean; Geophys. J. Int. 183 536-542.

Hammond J O S, Kendall J M, Collier J S and Rumpker G 2013 The extent of continental crust beneath the Seychelles; Earth Planet. Sci. Lett. 381 166-176.

Henstock T J and Thompson P J 2004 Self-consistent modelling of crustal thickness at Chagos-Laccadive Ridge from bathymetry and gravity data; Earth Planet. Sci. Lett. 224 325-336.

Kaila K L, Roy Chowdhury, Reddy P R, Krishna P R, Hari Narayan T, Subbotin S I, Sollogub V B, Chekuno A V, Kharetchko G E, Lazarenko M A and Llchenko T V 1979 Crustal structure along Kavali-Udipi profile in the Indian Peninsular shield from deep seismic sounding; J. Geol. Soc. India 20 307-333.

Krishna K S, Gopala Rao D and Sar D 2006 Nature of the crust in the Laxmi Basin $\left(14^{\circ}-20^{\circ} \mathrm{N}\right)$ western continental margin of India; Tectonics 25 TC1006, https://doi.org/ 10.1029/2004TC001747.

Kumar A, Pande K, Venkatesan T R and Baskar Rao Y J 2001 The Karnataka Late Cretaceous dykes as products of the Marion hot spot at the Madagascar-India breakup event: Evidence from 40Ar-39 Ar geochronology and geochemistry; Geophys. Res. Lett. 28 2715-2718.

Kunnummal P, Anand S P, Haritha C and Rama Rao P 2017 Moho depth variations over the Maldive Ridge and adjoining Arabian \& Central Indian basin, Western Indian Ocean, from three dimensional inversion of gravity anomalies; J. Asian Earth. Sci. 156 316-330, https://doi.org/10. 1016/j.jseaes.2017.12.012.

Kuo B Y and Forsyth D W 1988 Gravity anomalies of the ridge-transform system in the South Atlantic between 31 and $34.5^{\circ} \mathrm{S}$ : Upwelling centers and variations in crustal thickness; Mar. Geophys. Res. 10 205-232, https://doi. org/10.1007/BF00310065.

Luis F F and M C Neves 2006 The isostatic compensation of the Azores Plateau: A 3-D admittance and coherence analysis; J. Volcanol. Geotherm. Res. 156 1022.

Malod J A, Droz L, Kemal B M and Patriat P 1997 Early spreading and continental to oceanic basement transition beneath the Indus deep-sea fan: Northeastern Arabian Sea; Mar. Geol. 141 221-235.

McKenzie D and Bowin C 1976 The relationship between bathymetry and gravity in the Atlantic Ocean; J. Geophys. Res. 81 1903-1915.

McNutt M K 1988 Thermal and mechanical properties of the Cape Verde Rise; J. Geophys. Res. 93 2784-2794.

Minshull T A, Lane C I, Collier J S and Whitmarsh R B 2008 The relationship between rifting and magmatism in the northeastern Arabian Sea; Nat. Geosci. 1463 467.

Mishra A, Chaubey A K, Sreejith K M and Kumar S 2018 Crustal underplating and effective elastic plate thickness of the Laxmi Ridge, northern Arabian Sea; Tectonophys. $74482-92$.

Morgan W J 1972 Platemotions and deep mantle convection; Geol. Soc. Am. Memoir 132 7-22.
Müller R D, Sdrolias M, Gaina C and Roest W R 2008 Age, spreading rates, and spreading asymmetry of the world's ocean crust; Geochem. Geophys. Geosyst. 9 Q04006, https://doi.org/10.1029/2007GC001743.

Murty A V S, Arasu R T, Dhanawat B S and Subrahmanyam V S R 1999 Some aspects of deep water exploration in the light of new evidences in the western Indian offshore; In: Hydrocarbon exploration (ed.) Bhatnagar A K, Proceedings of the third international petroleum conference and exhibition (Petrotech-99), pp. 457-463.

Naini B R and Talwani M 1983 Structural framework and the evolutionary history of the continental margin of western India; In: Studies in continental margin geology (eds) Watkins J S and Drake C L, Am. Assoc. Pet. Geol. Mem. 34 167-191.

Nair N, Anand S P and Rajaram M 2013 Tectonic framework of Laccadive Ridge in western continental margin of India; Mar. Geol. 346 79-90.

Narain H, Kaila K L and Verma R K 1968 Continental margins of India; Can. J. Earth Sci. 5 1051-1065.

Parker R L 1972 The rapid calculation of potential anomalies; Geophys. J. Roy. Astron. Soc. 31 447455.

Parsons B and Sclater J G 1977 An analysis of the variation of the ocean floor bathymetry and heat flow with age; J. Geophys. Res. 82 803-827.

Radhakrishna T, Dallmeyer R D and Josheph M 1994 Palaeomagnetism and $36 \mathrm{Ar} / 40 \mathrm{Ar}$ isotope correlation ages of dyke swarms in central Kerala, India: Tectonic implications; Earth Planet. Sci. Lett. 121 213-226.

Radha Krishna M, Verma R K and Purushotham A K 2002 Lithospheric structure below the eastern Arabian Sea and adjoining west coast of India based on integrated analysis of gravity and seismic data; Mar. Geophys. Res. 23 25-42.

Ribe N M 1982 On the interpretation of frequency response functions for oceanic gravity and bathymetry; Geophys. J. Roy. Astron. Soc. 70 273-294.

Royer J-Y, Chaubey A K, Dyment J, Bhattacharya G C, Srinivas K, Yatheesh V and Ramprasad T 2002 Paleogene plate tectonic evolution of the Arabian and Eastern Somali basins; In: The tectonic and climatic evolution of the Arabian Sea region (eds) Clift P D, Kroon D, Gaedicke $\mathrm{C}$ and Craig J, Geol. Soc. London 195 7-23.

Sandwell D T and Smith W H F 2009 Global marine gravity from retracked Geosat and ERS-1 altimetry: Ridge segmentation versus spreading rate; J. Geophys. Res. 114 B01411.

Sandwell D T, Müller R D, Smith W H F, Garcia E and Francis R 2014 New global marine gravity model from CryoSat-2 and Jason-1 reveals buried tectonic structure; Science 346 65-67.

Smith W H F, Staudigel H, Watts A B and Pringle M S 1989 The Magellan seamounts: Early cretaceous record of the South Pacific Isotopic and thermal anomaly; J. Geophys. Res. 94 10,501-10,523.

Sreejith K M and K S Krishna 2013 Spatial variations in isostatic compensation mechanisms of the Ninetyeast Ridge and their tectonic significance; J. Geophys. Res. $1185165-5184$.

Sreejith K M and Krishna K S 2015 Magma production rate along the Ninetyeast Ridge and its relationship to Indian 
plate motion and Kerguelen hot spot activity; Geophys. Res. Lett. 42 1105-1112.

Sreejith K M, Krishna K S and Bansal A R 2008 Structure and isostatic compensation of the Comorin Ridge, north central Indian ocean; Geophys. J. Int. 175 729741.

Storey M, Mahoney J J, Saunders A D, Duncan R A, Kelley S P and Coffin M F 1995 Timing of hot spot-related volcanism and the breakup of Madagascar and India; Science $267852-855$.

Talwani M and Reif C 1998 Laxmi Ridge - a continental sliver in the Arabian Sea; Mar. Geophys. Res. 20259 271.

Tiwari V M, Grevemeyer I, Singh B and Morgan J P 2007 Variation of Effective Elastic Thickness and melt production along the Deccan-Reunion hotspot track; Earth Planet. Sci. Lett. 264 9-21.

Todal A and Eldholm O 1998 Continental margin off western India and Deccan Large Igneous Province; Mar. Geophys. Res. 20 273-291.

Corresponding editor: N V Chalapathi RAO
Torsvik T H, Tucker R D, Ashwal L D, Carter L M, Jamtveit B, Vidyadharan K T and Venkataramana P 2000 Late Cretaceous India-Madagascar fit and timing of break-up related magmatism; Terra Nova 12 220-224.

Torsvik T H, Amundsen H, Hartz E H, Corfu F, Kusznir N, Gaina C, Doubrovine P V, Steinberger B, Ashwal L D and Jamtveit B 2013 A Precambrian microcontinent in the Indian ocean; Nat. Geosci. 6 1-5.

Watts A B 1978 An analysis of isostasy in the world's oceans, 1. Hawaiian-Emperor Seamount chain; J. Geophys. Res. 83 5989-6004.

Watts A B 2001 Isostasy and flexure of the lithosphere; Cambridge Univ. Press, Cambridge.

Whitmarsh R B 1974 Some aspects of plate tectonics in the Arabian Sea; Initial Reports of the Deep Sea Drilling Project 23 US Govt. Printing Office, Washington, pp. 527535.

Young R and Hill I A 1986 An estimate of the Effective Elastic Thickness of the Cape Verde Rise; J. Geophys. Res. 91 4854-4866. 